\title{
OPERATION ASKARI
}

\section{(A SUB-COMMANDER'S RETROSPECTIVE VIEW OF THE OPERATION)}

\author{
Brig R.S. Lord*
}

\section{INTRODUCTION}

By 1983 the war in SWA/Angola had developed a predictable cyclical pattern. The seasonal variations allowed SWAPO to take up the offensive during the summer passage of the Inter-tropical Convergence zone (ITCZ) across Northern South West Africa. The ITCZ is that low pressure belt of unstable moist air, that traverses southwards to the latitude of Rehoboth during late October and November and returns northwards across Owamboland in late January through to April. The passage of this belt gives rise to the phenomenon of the "small rains" before Christmas and the "big rains" from February to April.

The rainy season gave mobility to the SWAPO insurgents. It supplied the water they required for their trek to the south. The foliage on the trees and bushes provided concealment from the security forces. The very heavy rains washed out the tracks they had left, making follow-up difficult and they criss-crossed the full shonas to increase the difficulties of the trackers. Therefore, the SWAPO insurgency, usually commenced in late January of every new year and continued until the end of April, or early May, when the water started to dry up.

The onset of the dry season brought about a change in the tactical situation. SWAPO withdrew its forces to bases in Angola for the so-called "rehearsals" - the regrouping and retraining of their members, prior to the next year's incursion. With Swapo concentrated in bases, it became cost-effective for the SADF/SWATF to launch offensive operations into Angolan territory during the dry winter months. The mobility of vehicles in the torrential rains of summer was always considered a restricting factor.
For many years, up to the spring of 1983, this had been the pattern of the conduct of the war. A summer incursion by SWAPO PLAN and a semi-conventional/convential offensive by Security forces into Angola during the winter.

The military results of these activities were overwhelmingly in the favour of the security forces, as can be deduced from the following table of Operational losses:

\begin{tabular}{|c|c|c|}
\hline YEAR & SWAPO & SECURITY FORCES \\
\hline 1981 & 1494 & 61 \\
1982 & 1280 & 77 \\
1983 & 913 & 96 \\
\hline
\end{tabular}

The economic and socio-political effects on South West Africa and the SADF were however appreciable. To counter an insurgency requires the deployment of a large number of forces, in the ratio of about 1 insurgent to 8 security force personnel. The direct cost factor is therefore considerable, as is the insidious effect of keeping able bodied men out of the economic work force. An additional factor was the war weariness of the population. The war had become so predictable that it was difficult to foresee how this process of violence could be halted.

In an attempt to surprise the enemy and to alter the pattern of predictability, Operation Askari was planned. Bearing in mind the difficulties of mobile operations in the wet season, it was decided that Askari would be a semi-conventional operation using conventional arms against Swapo Plan, while they were still massed in their training bases before the start of their 1984 insurgency campaign. The timing of the operation proper was therefore set to commence just after the "little rains" in mid-December 1983. 


\section{PLANNING}

The planning for Askari was conceived and carried out at the $\mathrm{HQ}$ Sector 10 at Oshakati under the guidance of Brig J. Joubert for the ground forces and Col R.S. Lord for the Air plan.' From conception the plan was a joint plan, with the air involvement being in support of the ground forces objectives. The overall aim of the operation was "to prevent a Swapo special forces infiltration to the South". The operation had to begin in Nov 1983.

Among the general guidelines were the following :

a. The enemy must be stopped externally.

b. Deep reconnaissance coupled to offensive actions must be commenced at an early stage.

c. Maximum use of mobile elments for follow-ups must be made.

d. Security forces must operate proactively, not re-actively. e. Security forces must maintain the initiative.

f. An infiltration during 1984 must simply not take place. Not even 10 terrorists must successfully infiltrate. ${ }^{2}$

The SAAF aims for Askari were as follows:

a. To gain and maintain a favourable air situation over CahamaMulondo-Cuvelai.

b. To prevent the expansion of enemy air defence capabilities in the Mulondo-Quiteve-Cuvelai areas.

c. To expand the SAAF interdiction programme :
i. Up to Chibemba.
ii. North of Mulondo.
iii. Up to Cassinga.

d. Extend Maanskyn (Impala night operations) north of the $150 \mathrm{~km}$ line.

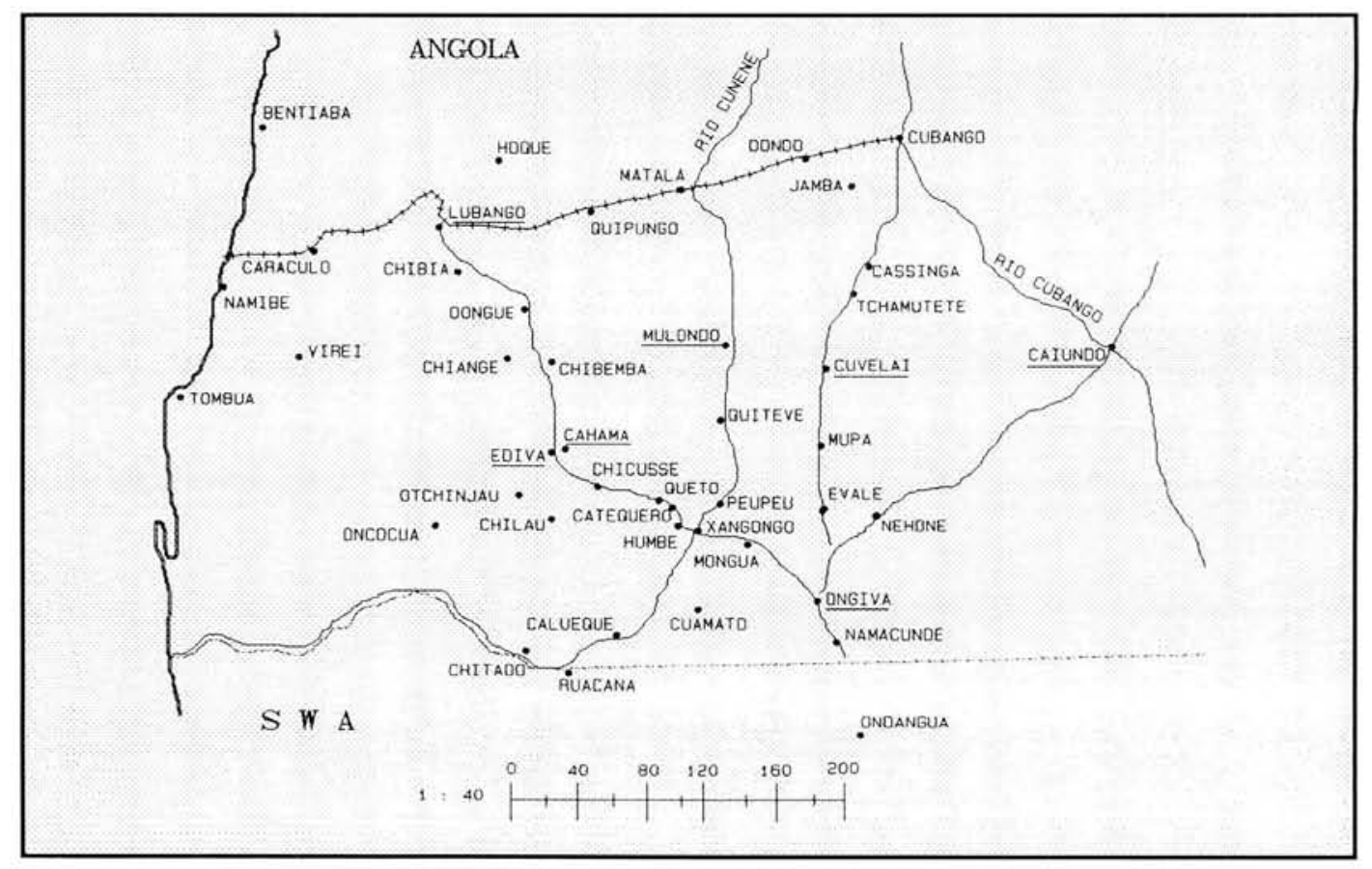

ANGOLA: 5 MILITARY REGION

\footnotetext{
' This plan should have been initiated at the strategic level of planning, ie Army/Air Force $H Q$ in Pretoria. It should have been part of the SADF military strategy. which in turn should have evolved out of the national strategy.

${ }^{2}$ In retrospect this guideline was totally impractical and should therefore not have been included.
} 
e. Preference was to be given to joint attacks on SWAPO targets. ${ }^{3}$

The plan was divided into four phases:

a. Phase 1. Deep reconnaissance by Special Forces followed by a SAAF attack on the "Typhoon"/ Volcano" base close to Lubango between 1 November and 30 December 1983.

b. Phase 2. Offensive reconnaissance/isolation of Cahama. Mulondo and Cuvelai from 16 November to mid January 1983. The aim being, to cut enemy communication and logistic lines in the deep area and to terrorise and demoralise Fapla to such an extent that they would withdraw.

c. Phase 3. To establish a dominated area from west of the Cunene River, through Quiteve, Mupa, Vinticet, eastwards through londe, by the beginning of Feb 1984.

d. Phase 4. The final stopping of the incursion, internally if necessary.

\section{PLAN APPROVAL}

The joint Army/Air Force plan was presented to GOC SWA and OC Western Air Command and approved without major alterations. It was then presented at Army $H Q$ to the Chief of the Defence Force. Present in the audience that day were 12 Generals plus one Admiral. At the presentation the Army plan was accepted in toto. The Air plan however, was only accepted after much discussion and much alteration. The reason for the changes being made are not open for discussion - but the fact remains that the Air plan was altered. ${ }^{4}$ Limits and restrictions were placed on the employment of the aircraft, which did not co-incide with the limits of action of the ground forces. In addition the deception strike on Caiundo was completely removed from the plan.

After all the discussions and alterations Askari was approved, to the relief of everyone present. At that stage everybody was glad to be able to come away with the authority to go ahead. I did not realise it at the time, but neither did the twelve Generals and one Admiral, that what had started life as a joint plan, was now no longer a balanced joint plan. What should have happened was that we should have gone "back to the drawing board" and rehashed the situation to once more come up with a joint plan. This was a vital lesson.

\section{RECONNAISSANCE ACTIVITIES PHASES 1 AND 2}

While I do not intend to go into detail about all the involvement of the "Recces", there are a few points that need to be brought up. It must be stated from the outset, that ASKARI called for the largest Recce effort of the war. A total of five teams of varying sizes were deployed. They were deployed west of Cahama, east of Cahama, in the vicinity of Mulondo, in the outskirts of Cuvelai and were also tasked to reconnoitre the Lubango area.

These teams provided the tactical intelligence on which the battle plans were made and in general performed a difficult task well. The command and control of these teams was however a bit of a problem from the Air Force point of view. Each team operated as a separate entity. Each team had its own tactical $\mathrm{HQ}$ at Xangongo - but each in a separate locality. The Air Force had provided a Mobile Air Operations Team (MAOT) to be co-located with the Army $H Q$ at Xangongo. Air support which had been promised to each of the recce teams was thus disjointed. The problem that could have arisen was one of priorities. If all the teams were in trouble, who would decide on the priority for air support?

\footnotetext{
${ }^{3}$ An additional Air Force aim was a night strike by Impalas on Caiundo. Although the FAPLA garrison stationed there was no real threat to our planned operation, the idea was to sow confusion in the minds of the FAPLA high command as to what our exact intentions with Askari were. This option was not authorised.

${ }^{4}$ It is my opinion that there was a personality clash between C SADF and OC Western Air Command. This I believe was the only reason that the air plan was changed.
} 


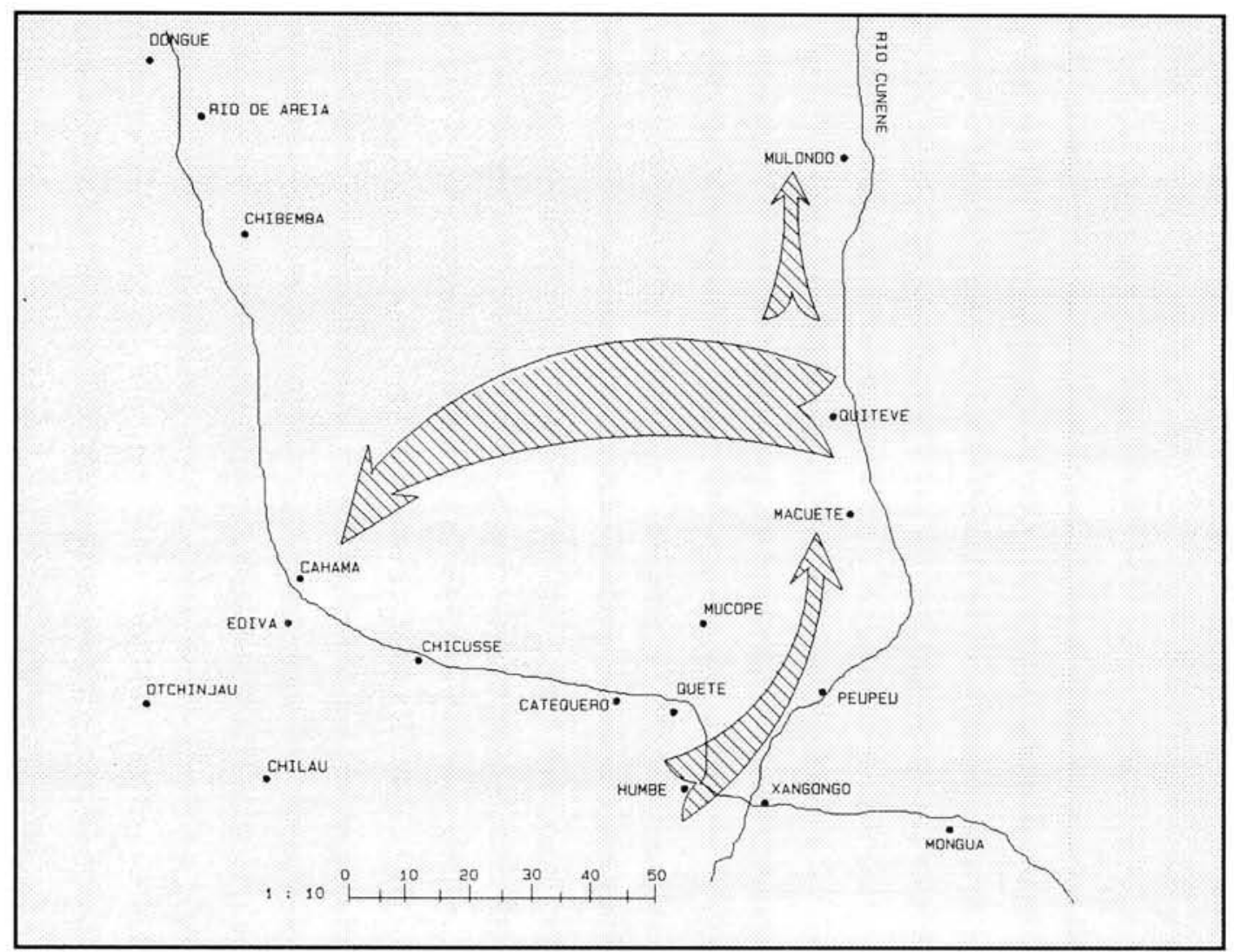

5 MILITARY REGION

In future, a joint $H Q$ is the only answer. with a representative of all involved parties present. ${ }^{5}$

At 0920B on 29 Dec 1983 four Buccaneers attacked the Tobias Hanyeko Training Centre, (THTC), just outside Lubango. This SWAPO training centre had over the years been responsible for the training of SWAPO recruits. From THTC they were posted straight to the various front headquarters. The aim of the strike was to demoralise the recruits before they had even left the safety of their training base. $32 \times 460 \mathrm{~kg}$ bombs were dropped into the target area. Approximately half of the bombs exploded on contact, and the others were fitted with delay fuzes from one to thirty six hours, rendering the centre uninhabitable. The air strike was on time on target and suffered no losses. Round one to the "Boere"!

\section{OFFENSIVE ACTIONS PHASE 2}

Chama. Throughout the duration of the war, Cahama had remained a tough nut to crack. FAPLA's 2nd Bri- gade had ensconced themselves in fortified positions in the environs of the little town, to the north and south of the Caculuvar river. Numerous forays and probes by our ground forces over the preceeding years had been undertaken against Cahama's perimeters. The Air Force had attacked radar and Anti-Aircraft Artillery (AAA) sites in the area on many occasions. None of these activities had succeeded in dislodging FAPLA, or in fact even denting the peripheral defences. Our analysis of the situation was that we had never concentrated all our effort into trying to take Cahama. If it had of been our aim, we could have taken the place.

FAPLA's analysis of the continual assaults was that they had always suceeded in chasing the "boere" away. They were therefore confident of their ability to hold Cahama, and contrary to our own widely disseminated intelligence on the troops in the town, their morale was in fact high.

61 Mechanised Battalion plus artillery were tasked to pressurise FAPLA's 2nd

${ }^{5}$ All arms of the service, particularly the Recces, tend to be parochial. That is, they plan within the limits of their own involvement. Although security of an operation is a definite factor, especially with clandestine operations, joint planning is always the best solution. 
Brigade, by probes, feints and artillery bombardments. Offensive recce teams were to cut FAPLA's logistic lines between Cahama and Chibemba, while the Air Force carried out strikes against identified targets within the defensive perimeter of the town. The combined results of these actions were to demoralise and terrorise the FAPLA and SWAPO forces, to such an extent, that they would either withdraw or desert from Cahama. It was envisaged that this "uitmergeling" would take place between 16 Nov 1983 and mid-January 1984. Time was required to allow all the desired effects to play their part.

In the event this was naive planning in the extreme. Between mid-November and mid-December the recce forces were indeed active, but a Brigade garrison, which in their view had successfully beaten off the "boere" repeatedly, would not be disturbed by the activities of two small recce teams. The real offensive pressure started around 16 December, with the advance of 61 Mechanised Battalion from the Quiteve area. This approach must have been detected by the defenders in Cahama. The bombing and bombardments which were then started and continued around the clock, must have had a detrimental effect on the defenders. Had the time limit of midJanuary been open-ended, then the plan might have been successful because by the end of December, the morale of the 2 nd Brigade was still reasonable.

It was known that SA-8 batteries were positioned about $2 \mathrm{kms}$ South West of the town, close to the road to Ediva. A sub-operation within Askari was Operation Fox. This called for a combined effort of ground and air forces to bomb and bombard in such a pattern, that the SA-8 batteries would be forced to change their position by moving to the south. The idea was to drive them out of the protective ring surrounding Cahama, into the vicinity of FAPLA's AAA defensive sites in the area of Ediva. Once in this area a concerted effort by the ground forces, (both Army and Recce), was to attempt to cap- ture an SA-8 system. This section of the overall Askari plan, was given top priority.

This plan was well on the way to succeeding. The SA-8 batteries had been forced to move their position twice, both times towards Ediva as planned. By the end of December, the clamouring in the world press to censure South Africa, because of the military presence in Angola, had reached a crescendo. A political decision was then made to cease all activities on the Cahama front by 31 December 1983.

All forces were withdrawn, FAPLA obviously breathed a sigh of relief, and the status quo around Cahama returned to normal. Once again the 2 nd Brigade had beaten off a determined assault by the "Boere". We lost that round!

Mulondo. The aim here was :

a. To isolate and demotivate FAPLA in both Quiteve and Mulondo to the extent that the troops would withdraw or desert.

b. To monitor the route MatalaMulondo-Quiteve, to see if Swapo was using it as an infiltration route.

The time period for this sub-operation was to be 16 Nov to 15 Jan ' 84 . The ground forces used would be the same that were to take Cuvelai. The Air Force was to carry out speculative bombing against selected targets, in and around Mulondo, to heighten the tension prior to the final assault by the ground forces.

On their advance towards Cahama 61 Mech took Quiteve almost without firing a shot. This phase was so successful that it was then decided to send a small fighting group with artillery support, northwards on the western side of the Cunene river, to begin the process of isolating Mulondo.

As a result of the high state of alert throughout Angola. FAPLA's 19th Brigade in Mulondo had sent out their

\footnotetext{
${ }^{6}$ Maintenance of the aim is a fundamental principle of war. All the effort put into the Cahama operation was not only wasted, it reinforced the enemies morale.
} 


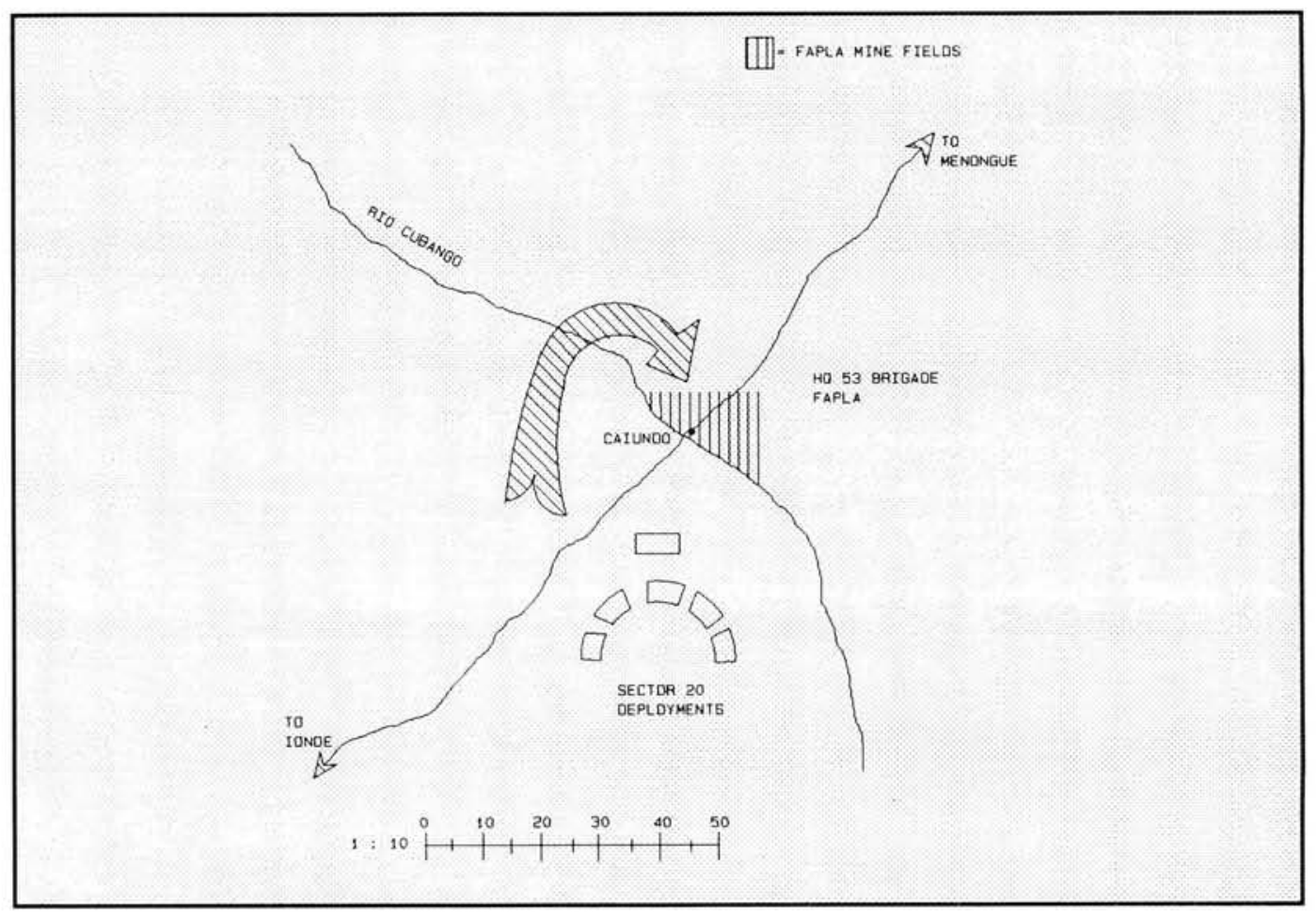

\section{ANGOLA : "PHASE 2 - CAIUNDO"}

own recce teams to protect their front. These troops performed an excellent task for FAPLA, in that they pin-pointed the position of our fighting team. They never used the intelligence to come out offensively against our forces but, whenever we moved our artillery into range, they proceeded to bombard our positions with their D-30 cannons. These guns outdistanced our artillery by 3 to $4 \mathrm{kms}$, which resulted in our forces having to undertake a quick withdrawal after firing just a few salvos.

This diversion from the original Askari plan, had repercussions on the air plan. Support had to be flown for the ground forces in the area, thus utilising aircraft hours and weapons that were set aside for the Cahama and Cuvelai battles. It had a further tactical disadvantage in that the element of surprise. that was to be gained with the air attacks on Cahama, was lost. After our Mulondo strikes the entire air defence system of Southern Angola was placed on the highest alert states.

On 23 Dec 83, 2 x Impalas attacked targets in the Mulondo area using
$68 \mathrm{~mm}$ rockets. The weather was atrocious with large cumulo-nimbus clouds. After the fourth attack in the area, the wingman was struck by a SAM in the tail, but he managed to land safely back at Ondangwa. ${ }^{8}$

The pre-amble to the plan for forcing FAPLA to leave Mulondo was unsuccessful. Political considerations in early January 1984 were such, that the SADF did not continue with the Askari plan for Mulondo. In the eyes of FAPLA's 19th Brigade they had succeeded in beating off a determined attack by the "Boere". We lost that round!

Caiundo. This small stronghold on the eastern bank of the Cubango river was never a part of the original Askari Army plan. The Air Plan however, had included a strike on the $H Q$ unit, as part of the overall deception plan. This request was not approved, and therefore no operational or logistical planning was carried out for operations in this eastern sector.

The offensive actions, as detailed in the Askari plan, commenced around

\footnotetext{
${ }^{7}$ Surprise, as a principle of war, has become even more important with the advent of SAM defences.

${ }^{8}$ Repeat attacks in the same target area are recipes for disaster!
} 
16 December. Both air and ground forces were engaged in offensive actions in the Quiteve-Mulondo-Cahama areas. Imagine my surprise, shortly thereafter, when I was casually informed that there was an Army group of ours that was deployed within 20 kms of Caiundo, on the western bank. When I enquired about their presence, I was told that they had been ordered to act as a deception force in that area and that they were in fact troops from Sector 20, who would otherwise not be utilised in Operation Askari.

This was never part of the joint Askari plan, and as such, it had a detrimental effect on the outcome of Askari. To londo fronts, to the unplanned for Caiundo area, which continued uninterrupted for the remainder of operation Askari. There was a substantial reduction in the air effort over the planned Askari key points, which reduced the pressure on the enemy and allowed FAPLA to remain in control of their troops and their emotions, in both Cahama and Mulondo.

In spite of a large air effort over a period of 21 days, Caiundo was not taken. Despite a heavy air bombardment and a determined ground assault the FAPLA minefields and defensive bunkers remained intact. FAPLA's 53rd Brigade had reason to celebrate their

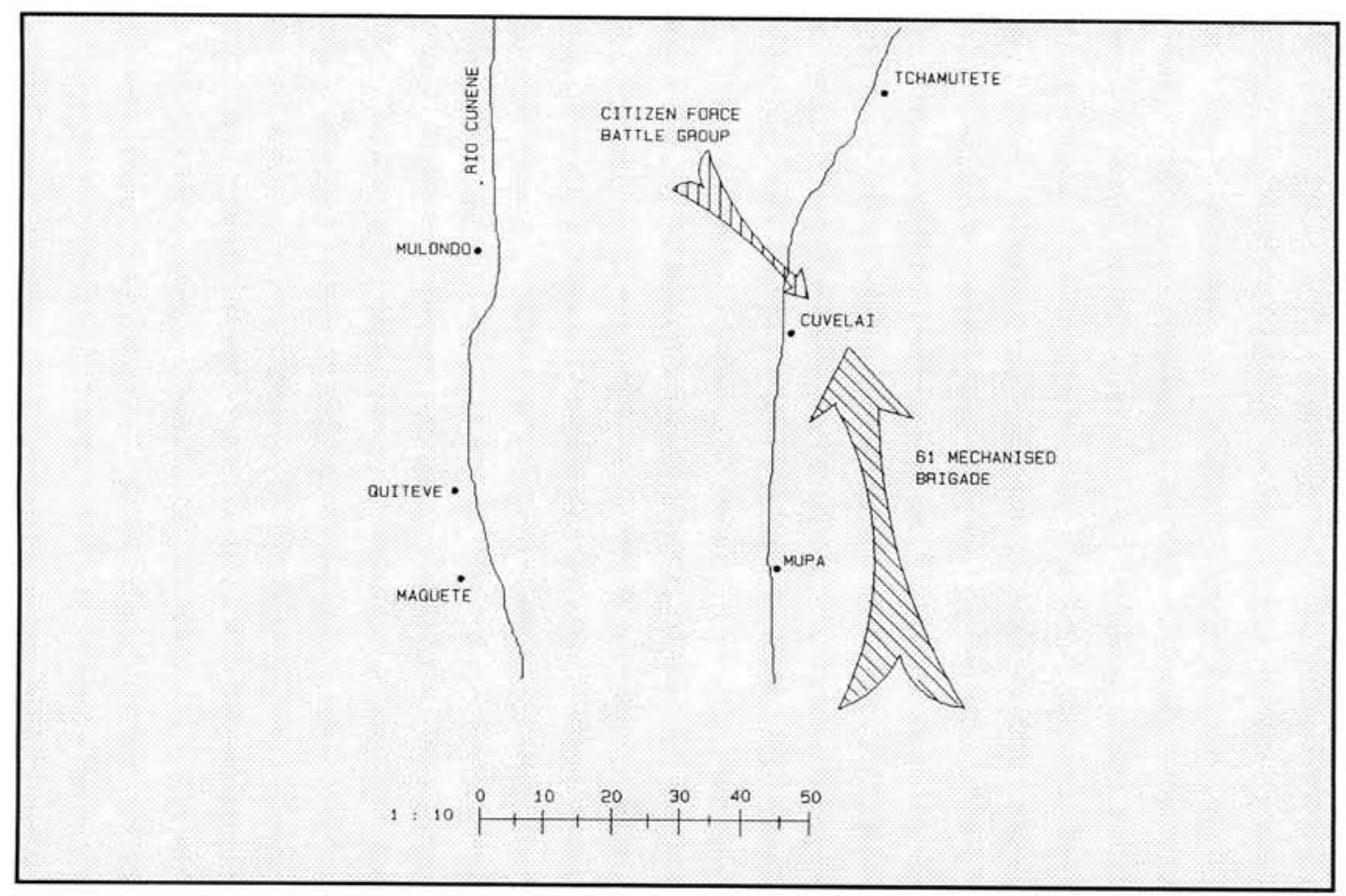

ANGOLA : "PHASE 2 - CUVELAI"

everyone's surprise and consternation, this force was attacked on the night of 19/20 December. FAPLA recces had discovered that one platoon of this force were deployed outside the main defensive perimeter, and were much closer to Caiundo than they should have been. During the night FAPLA sent a Company to attack this platoon. This they did successfully, killing five and capturing one SWA Territory Force soldier, plus 13 light machine guns, 3 rifles, 3 radios, a $60 \mathrm{~mm}$ mortar and a Unimog.

This set-back resulted in a switch of air activities from the Cahama and Mu- successful defence of Caiundo against the "Boere". We lost that round!

CUVELAI. Phase 2 of the original Army operational plan called for the isolation of Cuvelai, between 16 Nov 1983 and 15 January 1984. The aim was threefold:

a. To isolate, grind down "Uitmergel" and terrorise Cuvelai, to the extent that FAPLA would either leave on their own accord, or their soldiers would desert on a large scale.

b. To carry out operations against SWAPO elements such as the Mos- 
cow, Alpha and Bravo battalions in the Cuvelai area. c. To give early warning of a SWAPO
incursion.

The Air Force plan thus called for:

a. Extensive photo-recce of Cuvelai.

b. Speculative bombing day and night of SWAPO targets in the vicinity.

c. Air attacks on AAA sites that had a direct bearing on ground force operations.

In mid-December the photo-reconnaissance (PR) was flown, and up to date photos of all the AAA sites in Cuvelai were obtained. It must be remembered that in the history of our activities in Angola, the PR flights were always understood by the enemy to be the precursor of an attack. Round 1 of the psychological battle had been won!

On 27 December at 1405B, two Impalas dropped $10 \times 120 \mathrm{~kg}$ bombs on a SWAPO target in the area. At 1628B on the same day, four Canberras dropped 600 Alpha bombs, $2 \times 460 \mathrm{~kg}$ bombs and $16 \times 250 \mathrm{~kg}$ bombs on targets in and around the town.

The following day at 1335B, two Impalas carried out a further recce of the AAA sites in Cuvelai. At 1439B Canberras carried out attacks on targets close to the Cuvelai airstrip, dropping $17 \times$ $250 \mathrm{~kg}, 2 \times 460 \mathrm{~kg}$ as well as 300 Alpha bombs, which obtained a $90 \%$ coverage of the target. At $1610 \mathrm{~B}$ eight Impalas dropped $32 \times 250 \mathrm{~kg}$ bombs on various targets in and around the town.

All these flights were undertaken with the aim of achieving results against the enemies AAA defences, as well as obtaining the psychological advantage while attempting to grind-down (uitmergel) FAPLA.

The Army meanwhile had sent a battle group, consisting mainly of citizen force troops, to engage the SWAPO headquarters and logistic base $5 \mathrm{kms}$ north-east of the town. This group was attacked in turn by the FAPLA 11th Brigade and were in real danger of being cut-off. It was then decided to reassign 61 Mech under the command of Cmat Van Lill, who were then on the outskirts of Cahama, to assist the endangered battle-group. In a little over 16 hours, 61 Mech moved, under battle conditions, from the Cahama area, across the temporary bridge over the Cunene river to the outskirts of Cuvelai. This forced march was itself an epic of determination and perseverance, especially as those troops had to go straight into battle at Cuvelai when they arrived on 3 January 1984.

On the afternoon of 3 January the actual attack on Cuvelai took place. It commenced with a co-ordinated air attack aimed at all the known AAA and artillery sites. Each pilot was equipped with up to date enlarged photographs of his particular target. 10 Impalas led the raid, followed by 4 Canberras. Between them they dropped $60 \times 120 \mathrm{~kg}, 18 \times 250 \mathrm{~kg}, 2 \times$ $450 \mathrm{~kg}$ and 600 Alpha bombs. A second wave of Impalas dropped a further $32 \times 250 \mathrm{~kg}$ bombs. This was arguably the most effective strike flown by the SAAF, throughout the history of the war in Angola.

On completion of the air strike, an intercepted message from the $\mathrm{OC}$ of Cuvelai to his Lubango headquarters was picked up. The gist of what he said was "You better send help, 75\% of my artillery is out of action as a result of the SAAF bombardment."

The SAAF played another important role while supporting the ground forces as they attacked the town after the air strike. The Army was faced with two major problems - navigation through the minefields and the destruction of the last remaining resistance. Two Alouette gun-ships, led by Capt Carl Alberts, provided the assistance the Army required, against all doctrine and at great risk to themselves. Capt Alberts was awarded the Honorus Crux (HC) for his dedication to task.

After bogging down and losing a Ratel in the minefields, the ground forces entered Cuvelai to find that the enemies. 
both SWAPO and FAPLA, had fled. In fact, 32 Battalion who had troops in the Tetchamutete area, used these troops as stoppers to capture a large number of FAPLA who were running northwards.

The battle for Cuvelai was a success. Large amounts of war materiel were captured. The reason for the success was that for the only time during the four major battles that comprised Askari, air power was utilised correctly, followed by a determined assault by the ground forces. The aim was maintained and the concentration of forces, using a joint plan, overcame the enemy. Measured against the principles of war, this sub-operation was bound to succeed. The "Boere" won this round!

\section{INTERNATIONAL PRESSURE}

By the first week in 1984 the pressure on the South African government reached a peak. Our military presence and operations in Angola were being condemned from all quarters, with threats of even greater sanctions and boycotts. This pressure, plus the relatively slow progress of the weather hampered operation, made the politicians decide to halt Askari on 10 January 1984. Captured equipment was recovered to South West Africa and all participating forces were stood down.

\section{PHASE 3}

A dominated area was established by February 1984 that included all the territory between the Cunene and $\mathrm{Cu}$ bango rivers, as far north as a line running east/west through Tetchamutete. The area west of the Cunene was still "Injun territory", but for purposes of Askari it can be assumed that the "Boere" won that round.

\section{PHASE 4}

This phase was to be the final stopping of the incursion internally, if necessary. This always seemed to be a contradiction of the guide-lines set for Askari. A study of the results of operational losses for 1984 are an indication of whether this phase was successful or not. SWAPO suffered 916 dead in 1984 . of which 361 were killed during Askari. The remainder were as a result of the normal summer incursion. The one positive factor was the reduction in Security force deaths, from 96 in 1983 to 39 in 1984. 13 of these 39 were killed during Askari.

Nevertheless an incursion did occur, so it must be stated that the "Boere" lost that round.

\section{SUMMARY}

Over the years Askari has been looked on as a major success. This perception began right from the first de-brief held at Oshakati in February 1984. It certainly is true that:

a. We captured Cuvelai along with masses of war materiel.

b. FAPLA suffered a severe defeat in terms of men and equipment.

c. Apart from their successful attack on a platoon of ground forces outside Caiundo, FAPLA never achieved any other offensive success.

The question remains "Is it true that Askari was a success?"

The Rhodesians were fond of stating the fact that, "they never lost a battle" in their bush campaign, but they did lose their war! Did the same happen in Askari? Let us examine the facts.

Our acknowledged enemy was SWAPO. They used Angola as a safe harbour, from where they launched their attacks into South West Africa. After the initial large scale raid by the SADF to Cassinga during operation Reindeer, Swapo realised the inherent dangers of establishing permanent bases that could be attacked by the SADF. To protect their Headquarters and training establishments, they moved these facilities under and behind, the umbrella protection provided by the FAPLA forces, thus making FAPLA a "legitimate" target.

During December 1983 - January 1984 we lost 32 soldiers compared to the 407 
SWAPO terrorists that were killed. A ratio of nearly 13:1. The overall figures for 1983 were 96 security force to 913 SWAPO's, a ratio of just under 10:1. The ratio increased in 1984 to $23: 1$, so in that respect Askari reaped benefits and in fact for the remainder of the war this ratio stayed over 20:1. SWAPO PLAN never succeeded in regaining the offensive capability it had prior to Askari.

The overall aim of Askari however, was to prevent an infiltration to the south in 1984. 555 Terrorists were killed during 1984, in addition to those killed during Askari, indicating that although they suffered losses, the pattern of the insurgency war continued. We failed to achieve the main aim.

Phase 2 of the plan called for offensive action against FAPLA strongholds. We comprehensibly beat the 11 th Brigade at Cuvelai, but we did not achieve our goals at either Cahama or Mulondo. In addition we did not succeed in dislodging the FAPLA forces out of Caiundo. Seen out of FAPLAs'eyes, they lost Cuvelai but won the battles for Cahama. Mulondo and Caiundo.

Askari became the watershed in the course of the Angola/SWA war. SWAPO PLAN was reduced in military strength and from then onwards no longer posed a major threat. On the other hand FAPLA grew in stature and evolved into the major factor in the pursuance of our war against SWAPO. Our readiness to attack FAPLA, wherever or whenever they protected SWAPO, provoked them into aquiring an air defence system to protect their interests, that was second only to that assembled in the Warsaw pact countries.

Two significant events occurred after Askari. Firstly, initiatives were taken to bring the South Africans and the Angolans to the negotiating table. South Africa, being in the position of strength, welcomed the proposal as did the Angolans, who were suffering militarily and psychologically at that stage. South Africa saw the opportunity as a chance for peace in the region. Angola on the other hand siezed the opportunity as a tactic. Commu- nist inspired organisations have a history of going to the negotiating table whenever they are in trouble, and then utilising the breathing space to re-plan. re-organise and re-equip. This is precisely what they did during the protracted life of the Joint Monitoring Commission (JMC), that was brought into being for the purposes of negotiations.

The second significant occurrence was the subtle change in the whole structure of the war. FAPLA gradually replaced SWAPO as our main enemy. The war entered a phase of greater sophistication and the low intensity counter-insurgency bush war, escalated over the next four years, to a high intensity undeclared conventional war, between the armed forces of the RSA, SWA and UNITA, on the one hand, and FAPLA, the Cubans plus their Russian advisors, on the other.

The war was no longer a regional conflict. It had become internationalised and as such the solution was no longer in the hands of SWAPO or the RSA. An international solution had to be sought with all the accompanying implications.

\section{CONCLUSION}

"Was Askari a success?" It can be fairly stated, that as an operation against SWAPO. Askari produced results that effectively eliminated SWAPO PLAN as a major element in the military struggle. Although the organisation still existed, their military efforts had lost potential and were easily countered. Although we required a large economic outlay to maintain this status quo, they realised and we realised, that they could not beat us militarily. In this aspect Askari was successful.

I do not believe that the consequences of Askari, in terms of factors other than SWAPO, were originally envisaged. The four years, from 1984 to the culmination of hostilities outside Cuito Canevale and Calueque in 1988, stretched our reserves and capabilities severely. The wholesale build up of Soviet arms, within this time period, created a situation that was becoming 
daily more difficult to handle. The cost factor in terms of both men and materiel was placing a critical burden on our resources.

The internationalisation of the conflict led to us becoming increasingly involved with extricating UNITA from situations that they could not handle. These unmanageable situations for the guerilla forces of UNITA were brought about by their inability to counter heavy equipment, such as the tanks, helicopters and artillery, that FAPLA had aquired specifically to counter South African attacks. These factors lend support to the belief that the conventional attacks on Fapla, during
Askari, had repercussions that affected the entire future of the war.

Many lessons can be extracted from the limited success of Askari, that affect all levels of authority in the Republic. An operation of the magnitude of Askari requires vetting and authority to be granted at Sector, Theatre, Chief of Staff and Cabinet level. War is an ugly thing which possesses the potential to escalate beyond imagination. Before one commits forces to battle, it must be ensured, that the operation is in accordance with the countries military strategy, that in turn must be part of the national strategy. No future operation should be approved that does not satisfy these two criteria.

* Brig R.S. Lord, Officer Commanding AIR FORCE COMMAND POST

\section{GLOSSARY OF TERMS}

ALPHA BOMB. A circular shaped anti-personnel bomb weighing 6 kg's. Dropped from level flight that gave a natural dispersion pattern. The bomb would strike the surface activating the fuzing mechanism, and then bounce into the air to explode about 6 meters above the ground. This bomb was an improved version of that used by the Rhodesian Air Force and 300 of them could be loaded into the bomb-bay of the Canberra bomber.

AAA (Anti-aircraft artillery). Triple A was the overall term used to describe the anti-aircraft guns that were employed in a limited manner by SWAPO, but extensively by the Angolan Defence Force. These guns covered the complete range of Soviet supplied weaponry and include the following :

\section{a. $12,7 \mathrm{~mm}$ \\ b. $\quad 14,5 \mathrm{~mm}$ \\ c. $20,0 \mathrm{~mm}$}

d. $23,0 \mathrm{~mm}$ Note This included the towed twin barrelled version which was probably the most widely used and effective gun used in the entire campaign by either side, both in the ground to air and ground to ground mode. The four barrelled tracked version (Shilka) was also utilised.

e. $37,0 \mathrm{~mm}$

f. $\quad 57.0 \mathrm{~mm}$ Note. These radar guided guns were originally equipped with the fire-can radar, and later this was updated with the flap-wheel system.
"Boere". A general useage term used by both SWAPO and the Angolans to describe the RSA/SWATF security forces.

HC (Honoris Crux). The highest decorations for military valour that can be awarded to members of the South African Defence Force. There are three classes namely :

a. Bronze $\mathrm{HC}$

c. Silver HCS

c. Gold $\mathrm{HCG}$

JMC (Joint Monitoring Commission). This commission was brought into being by the recognised need by both the South African and Angolan antagonists to establish a forum wherein matters that could lead to a peaceful settlement were to be discussed. The jointness of the commission was emphasised by the fact that members of the Defence Forces and Foreign Affairs departments of both countries were included. It was only after the second JMC was formed, after operations Moduler, Hooper and Packer, that a final peaceful settlement was negotiated.

LMG - Light machine gun

MAANSKYN. The name given to the highly successful night interdiction operations that were carried out by Impala aircraft from the early 1980's until the cessation of the war. A highly skilled form of flying requiring intense 
concentration, that dominated the battle area of Angolas Cunene province for a large period of the war.

MAOT (Mobile Air Operations Team). These small teams were usually under the command of a Pilot with Majors rank, and consisted of an Operations Officer, an Intelligence Officer and a radio operator. They were sometimes deployed by air, but were more often mounted in Buffel, Ratel and later Casspir vehicles. They were co-located with the Army ground commander for internal (within SWA) and external operations. Their main function was to assist the ground forces commander with planning for his air requirement, and the liason back to the next Air Force Headquarters.

PR (Photographic Reconnaissance). A most important intelligence gathering function of the Air Force. Good up to date photography often meant the difference between success and failure of air operations.

Recces, A general term of common useage that could be used to describe:

a. A member or Unit of the South African Reconnaissance Regiment.

b. A ground intelligence gathering operation.

c. A special air sortie aimed at gaining intelligence.

RSA - Republic of South Africa

Shona. An open area in the bush that fills with water during the rainy season, and is invariably dry during the winter months.

SAAF - South African Air Force

SADF - South African Defence Force

SWA - South West Africa (Now Namibia)

SWAPO - South West African Peoples Organisation (A misnomer as the organisation truly represented only the Owambo people)

SWAPO PLAN (The Peoples Liberation Army of Namibia). The militant wing of SWAPO that used the territory of neighbouring states from which to launch attacks against the peoples and state representatives of the South West African government.
SAM (Surface to Air Missile). A missile, guided by either infra red or radar, fired from a launcher on the ground at an airborne target. By the end of the war the Angolans had an array of missiles that included the following :
a. SAM-2 Fixed site
b. SAM-3 Fixed site
c. SAM-6 Mobile tracked
d. SAM-7 Shoulder launched
e. SAM-8 Mobile wheeled
f. SAM-9 Mobile wheeled
g. SAM-13 Mobile tracked
h. SAM-14 Shoulder launched
i. SAM-16 Shoulder launched

Note : During Askari an Impala was hit at Mulondo by a SAM-7 while another had his right tailplane removed by a SAM-9 over Cuvelai. Both aircraft returned with battle damage. The first to its base at Ondangwa, while the second landed at Ongiva. This Angolan base had been resurfaced by the Airfield Maintenance Unit of the SAAF shortly before this emergency.

TYPHOON. The name given by SWAPO to their elite group of most highly trained troops, whose specific task was the infiltration of SWA. Although highly prized by SWAPO they did not in fact achieve any more notable successes than their normal PLAN contemporaries.

UNIMOG. A four by four transport vehicle, based on a Mercedes Benz chassis and engine, that bore the brunt of bush operations until SWAPO mine-laying forced the introduction of mineprotected vehicles.

UNITA. The breakaway party led by Jonas Savimbi that was eventually supported by the western powers, including South Africa, in the fight against the communist backed MPLA in Angola. It must be noted that it was in the interest of the RSA to support UNITA, as their presence protected the long SWA border from the eastern edge of Owamboland right through to the end of the Caprivi strip. from SWAPO insurgency.

"Uitmergel". An Afrikaans word that literally translated means to exhaust or grind down.

Volcano. The name given by SWAPO to the training base approximately 14 kilometers north east of Lubango. where specialised training was conducted for their Typhoon troops. 